\title{
PENGARUH RETURN ON ASSET (ROA) DAN EARNING PER SHARE (EPS) TERHADAP HARGA SAHAM PADA PT. ASURANSI RAMAYANA, TBK PERIODE 2010-2019
}

\author{
${ }^{*}$ Nani, ${ }^{2}$ Saeful Sidik \\ Universitas Pamulang, Tangerang Selatan, Banten, Indonesia \\ *dosen01704@unpam.ac.id
}

\begin{abstract}
Abstrak
Penelitian ini bertujuan untuk mengetahui pengaruh Return On Asset (ROA) dan Earning Per Share (EPS) terhadap Harga Saham PT.Asuransi Ramayana Tbk. Periode 2010-2019 jenis penelitian ini adalah kuantitatif. Metode penelitian yang digunakan adalah metode regresi linear berganda menggunakan uji t dan uji F dengan variable 1 Return On Asset (ROA), variable 2 Earning Per Share (EPS) dan variable Y Harga Saham. Jenis data yang dignakan adalah data sekunder. Berdasarkan hasil penelitian menunjukan bahwa besarnya pengaruh Return On Asset (ROA) dan Earning Per Share (EPS) terhadap Haraga Saham dengan koefisien determinasi KD= 80,10\% sedangkan sisanya 19,90\% dipengaruhi oleh variabel lain. Secara simultan variable Return On Asset (ROA) dan Earning Per Share (EPS) secara bersama-sama berpengaruh signifikan terhadap harga saham. Hal ini di tunjukan oleh hasil uji F dengan nilai Fhitung 14.073 lebih besar dari Ftabel 4,74 dengan signifikan 0,004 lebih kecil dari 0,05 atau (Fhitung > FTabel) dan Fsignifikan < 0,05).
\end{abstract}

Kata Kunci: Return On Asset (ROA), Earning Per Share (EPS), Harga Saham

\section{Abstract}

This study aims to determine the effect of Return On Assets (ROA) and Earning Per Share (EPS) on the stock price of PT. Asuransi Ramayana Tbk. The period 2010-2019 this type of research is quantitative. The research method used is multiple linear regression method using t test and F test with variable 1 Return On Assets (ROA), variable 2 Earning Per Share (EPS) and variable Y Stock Price. The type of data used is secondary data. Based on the results of the study showed that the magnitude of the influence of Return On Assets (ROA) and Earning Per Share (EPS) on stock prices with a coefficient of determination KD $=80.10 \%$ while the remaining $19.90 \%$ was influenced by other variables. Simultaneously, the Return On Assets (ROA) and Earning Per Share (EPS) variables have a significant effect on stock prices. This is shown by the results of the F test with an Fcount of 14.073 greater than Ftable 4.74 with a significant 0.004 less than 0.05 or (Fcount $>$ FTable) and Fsignificant $<$ $0.05)$

Keywords: Return On Asset (ROA), Earning Per Share (EPS), Stock Price

\section{PENDAHULUAN}

Pada era globalisasi saat ini, setiap organisasi atau perusahaan yang berbentuk pemerintah maupun swasta tentunya memiliki tujuan baik itu dalam jangka pendek maupun jangka panjang yang hendak dicapai melalui aktivitas yang dilakukan, agar tujuan yang telah ditetapkan dapat tercapai. Seraca umun, manajemen dipandang sebagai sebuah disiplin ilmu yang mengajarkan tentang proses untuk memperoleh tujuan organisasi. Manajemen yang baik akan memudahkan terwujudnya tujuan perusahaan, karyawan, dan masyarakat.

Perusahaan merupakan suatu organisasi yang menggabungkan dan mengorganisasikan berbagai sumber daya dengan tujuan untuk memproduksi barang dan jasa guna untuk dijual. Adapun tujuan perusahaan adalah untuk memaksimalkan nilai perusahaan dan mensejahterakan para pemegang saham. Memaksimalkan nilai pemegang saham dapat ditempuh dengan cara memaksimalkan nilai sekarang atau "present value", semua keuntungan pemegang saham yang diharapkan dapat diperoleh di masa yang akan datang. 
Harga saham merupakan nilai sekarang dari penghasilan yang akan diterima oleh pemodal dimasa yang akan datang. Harga saham menunjukkan prestasi perusahaan yang bergerak searah dengan kinerja perusahaan. Perusahaan yang memiliki prestasi yang baik dapat meningkatkan kinerja perusahaannya yang tercermin dari laporan keuangan perusahaan, sehingga investor akan tertarik untuk berinvestasi pada perusahaan tersebut. Peningkatan permintaan investor terhadap perusahaan tersebut akan menyebabkan harga saham perusahaan yang bersangkutan cenderung meningkat pula. Laporan keuangan perusahaan dapat menjadi acuan bagi investor dalam pengambilan keputusan investasi, seperti menjual, membeli atau menanam saham. Harga saham setiap waktu dapat berubahubah tergantung pada besarnya penawaran dan permintaan investor akan saham tersebut.

Faktor-faktor yang dapat memengaruhi naik turunnya harga saham suatu perusahaan adalah faktor internal dan faktor eksternal perusahaan tersebut. Penelitian ini menggunakan faktor internal perusahaan yang tercermin dalam laporan keuangan perusahaan. Faktor internal perusahaan yang digunakan berupa rasiorasio keuangan seperti rasio profitabilitas yang diproksikan dengan Return on Asset (ROA) dan rasio pasar yang diproksikan dengan Earning Per Share (EPS).

Return On Asset (ROA) adalah rasio profitabilitas yang mengukur seberapa besar perusahaan dapat meningkatkan laba bersih perusahaan dengan menggunakan seluruh asset yang dimiliki perusahaan. Semakin besar ROA menunjukkan bahwa keuntungan/laba yang dicapai perusahaan semakin besar, sehingga akan menarik minat investor untuk menanamkan modalnya pada perusahaan tersebut. Meningkatnya permintaan akan saham tersebut nantinya akan dapat meningkatkan harga saham perusahaan tersebut di pasaran.

Earning Per Share (EPS) merupakan rasio pasar yang digunakan untuk mengukur seberapa besar pengakuan pasar akan suatu perusahaan dengan membandingkan antara laba bersih dengan jumlah lembar saham yang beredar di pasaran. Earning Per Share (EPS) yang meningkat menandakan bahwa perusahaan berhasil meningkatkan kemakmuran investor dengan berupa pembagian dividen. Hal ini dapat meningkatkan permintaan investor akan saham yang nantinya akan menyebabkan semakin meningkat pula harga saham perusahaan tersebut.

Penulis memilih rasio Return On Asset (ROA) sebagai variable $\mathrm{X} 1$, dimana sebagai alat analisis harga saham, karena Return On Asset (ROA) merupakan rasio yang mewakili pengambilan atas seluruh aktivitas perusahaan. Sementara Earning Per Share (EPS) sebagai variable X2. karena EPS menunjukkan berapa rupiah laba yang diterima investor atas setiap lembar saham. Kedua variabel tersebut diduga menjadi pertimbangan para investor dalam membeli saham dan memiliki keuntungan dapat mepengaruhi harga saham. Berikut ini adalah Tabel Hasil Return On Asset (ROA) PT.Asuransi Ramayana Tbk Tahun 20102019:

Tabel 1. Hasil Data Return On Asset (ROA) PT. Asuransi Ramayana Tbk. Tahun 2010 - 2019

\begin{tabular}{|c|c|}
\hline Tahun & $\begin{array}{c}\text { Return On Asset } \\
\text { (ROA) } \%\end{array}$ \\
\hline 2010 & 5.33 \\
\hline 2011 & 6.13 \\
\hline 2012 & 3.09 \\
\hline 2013 & 2.96 \\
\hline 2014 & 4.31 \\
\hline 2015 & 4.45 \\
\hline 2016 & 4.41 \\
\hline 2017 & 4.26 \\
\hline 2018 & 4.80 \\
\hline 2019 & 3.98 \\
\hline
\end{tabular}

Sumber: Laporan keuangan PT. Asuransi Ramayana Tbk. Data diolah.

Pada Tabel 1. perhitungan Return on Asset (ROA) PT.Asuransi Ramayana.Tbk mengalami fluktuatif setiap tahunnya, terlihat pada tahun 2010 sebesar 5,33\% dan pada tahun 2011 mengalami peningkatan sebesar 6,13\%, akan tetapi di tahun 2012 terjadi penurunan menjadi $3.05 \%$ dan mengalami penurunan di tahun 2013 
menjadi 2,96\%. Pada tahun 2014 terjadi peningkatan yaitu sebesar $4,31 \%$ dan terjadi peningakatan kembali di tahun 2015 sebesar 4,45\% akan tetapi pada tahun 2016 terjadi penurunan menjadi $4,41 \%$ dan 2017 penurunan kembali terjadi menjadi $4,26 \%$. Pada tahun 2018 terjadi peningkatan menjadi $4.80 \%$ dan terjadi penurunan menjadi 3,98\% pada tahun 2019. Berdasarkan hasil data perhitungan presentase Return On Asset (ROA), yang disajikan dalam Tabel 1. tersebut di atas dapat dilihat perubahan nilainya melalui bentuk grafik berikut ini:

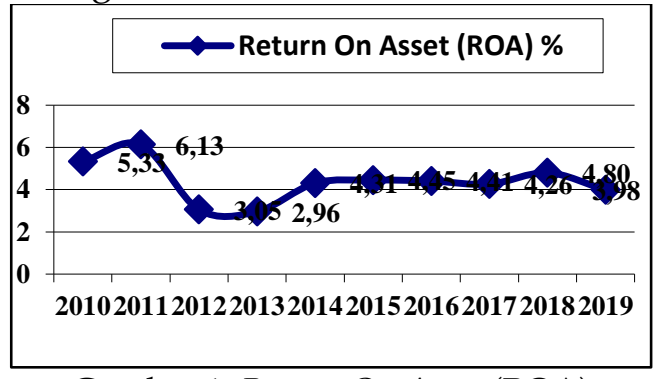

Gambar 1. Return On Asset (ROA)

Return On Asset (ROA) adalah rasio profitabilitas yang mengukur seberapa besar perusahaan dapat meningkatkan laba bersih perusahaan dengan menggunakan seluruh asset yang dimiliki perusahaan. Semakin besar ROA menunjukkan bahwa keuntungan/laba yang dicapai perusahaan semakin besar, sehingga akan menarik minat investor untuk menanamkan modalnya pada perusahaan tersebut. Meningkatnya permintaan akan saham tersebut nantinya akan dapat meningkatkan harga saham perusahaan tersebut di pasaran.

Menurut Kasmir (2013:207), mendefinisikan Earning Per Share (EPS) sebagai berikut : "Rasio laba per lembar saham atau disebut juga rasio nilai buku, merupakan rasio untuk mengukur keberhasilan manajemen dalam mencapai keuntungan bagi pemegang saham."

Menurut Darmadji \& Fakhrudin (2012:154), mendefinisikan Earning Per Share (EPS) sebagai berikut: "Earning Per Share (EPS) adalah rasio yang mencerminkan kemampuan perusahaan dalam menghasilkan laba untuk setiap lembar saham yang beredar".
Menurut Irham Fahmi (2012:96), mendefinisikan earning per share sebagai berikut: "Earning Per Share (EPS) adalah bentuk pemberian keuntungan yang diberikan kepada para pemegang saham dari setiap lembar saham yang dimiliki."

Tabel 2. Hasil Data Perhitungan Earning Per

Share (EPS) PT.Asuransi Ramayana Tbk.

\begin{tabular}{|c|c|} 
Tahun $2010-2019$ \\
\hline Tahun & $\begin{array}{c}\text { Earning Per } \\
\text { Share (EPS) }\end{array}$ \\
\hline 2010 & 229.16 \\
\hline 2011 & 223.80 \\
\hline 2012 & 154.00 \\
\hline 2013 & 160.90 \\
\hline 2014 & 278.38 \\
\hline 2015 & 295.13 \\
\hline 2016 & 295.19 \\
\hline 2017 & 281.55 \\
\hline 2018 & 330.66 \\
\hline 2019 & 286.79 \\
\hline
\end{tabular}

Pada perhitungan Earning Per Share (EPS) PT.Asuransi Ramayana.Tbk juga mengalami fluktuatif setiap tahunnya, terlihat pada tabel 1.2, Earning Per Share pada tahun 2010 sebesar 229,16 dan terjadi penurunan pada tahun 2011 sebesar 223,80, pada tahun 2012 kembali turun menjadi 154,00. Pada tahun 2013 Earning Per Share mengalami peningkatan kembali pada 160,90 ditahun 2014 mengalami kenaikan yang cukup signifikan menjadi 278,38 dan mengalami peningkata kemblai menjadi 295,13 ditahun 2015. Sedangkan pada tahun 2016 Earning Per Share terjadi kenaikan menjadi 295,19 dan terus turun di tahun 2017 menjadi 281,55. Pada tahun 2018 Earning Per Share mengalami peningkatan sebesar 330,66\% dan turun di tahun 2019 menjadi 286,79. Berdasarkan hasil data perhitungan presentase Earning Per Share (EPS), yang disajikan dalam Tabel 2. tersebut di atas dapat dilihat perubahan nilainya melalui bentuk grafik berikut ini:

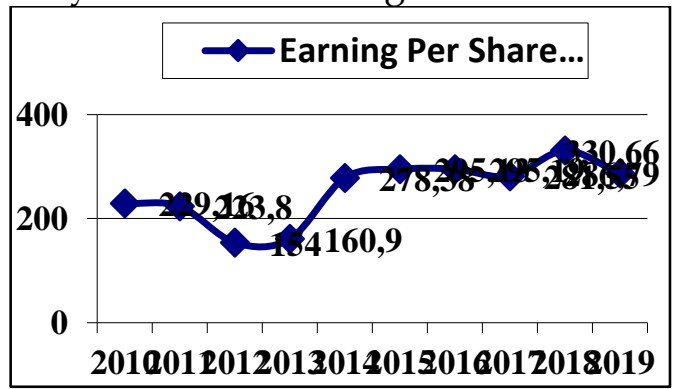

Gambar 2. Earning Per Share (EPS) 
Earning Per Share (EPS) merupakan rasio pasar yang digunakan untuk mengukur seberapa besar pengakuan pasar akan suatu perusahaan dengan membandingkan antara laba bersih dengan jumlah lembar saham yang beredar di pasaran. EPS yang meningkat menandakan bahwa perusahaan berhasil meningkatkan kemakmuran investor dengan berupa pembagian dividen. Hal ini dapat meningkatkan permintaan investor akan saham yang nantinya akan menyebabkan semakin meningkat pula harga saham perusahaan tersebut.

Harga saham merupakan nilai sekarang dari penghasilan yang akan diterima oleh pemodal dimasa yang akan datang. Harga saham menunjukkan prestasi perusahaan yang bergerak searah dengan kinerja perusahaan. Perusahaan yang memiliki prestasi yang baik dapat meningkatkan kinerja perusahaannya yang tercermin dari laporan keuangan perusahaan, sehingga investor akan tertarik untuk berinvestasi pada perusahaan tersebut. Peningkatan permintaan investor terhadap perusahaan tersebut akan menyebabkan harga saham perusahaan yang bersangkutan cenderung meningkat pula.

Tabel 3. Hasil Data Harga Saham PT.Asuransi Ramayana Tbk. Tahun 2010 - 2019

\begin{tabular}{|c|c|}
\hline Tahun & $\begin{array}{c}\text { Harga Saham } \\
\text { Rp }\end{array}$ \\
\hline 2010 & 360 \\
\hline 2011 & 622 \\
\hline 2012 & 980 \\
\hline 2013 & 1000 \\
\hline 2014 & 1,285 \\
\hline 2015 & 2,500 \\
\hline 2016 & 2,690 \\
\hline 2017 & 2,280 \\
\hline 2018 & 2,350 \\
\hline 2019 & 2,020 \\
\hline
\end{tabular}

Berdasarkan data tabel di atas kita dapat mengetahui bahwa harga saham PT.Asuransi Ramayana Tbk. dari tahun ke tahun mengalami fluktuatif. Hal ini dapat di lihat pada tahun 2010 harga saham mempunyai nilai sebesar Rp.360 mengalami kenaikan mulai dari tahun 2011 sebesar Rp.622, Tahun 2012 mengalami kenaikan sebesar Rp.980 dan 2013 sebesar Rp1,000, tahun 2014 sebesar Rp.1,285 lalu pada tahun
2015 sebesar Rp.2,500, tahun 2016 sebesar Rp.2,690. Harga saham terjadi penurunan di tahun 2017 yaitu sebesar Rp.2.280, akan tetapi mengalami kenaikan kembali pada tahun 2018 sebesar Rp.2,350 dan di tahun 2019 penurunan kembali terjadi pada harga Rp.2,020.

Berdasarkan hasil data perhitungan Harga Saham yang disajikan dalam Tabel tersebut di atas dapat dilihat perubahan nilainya melalui bentuk grafik berikut ini:

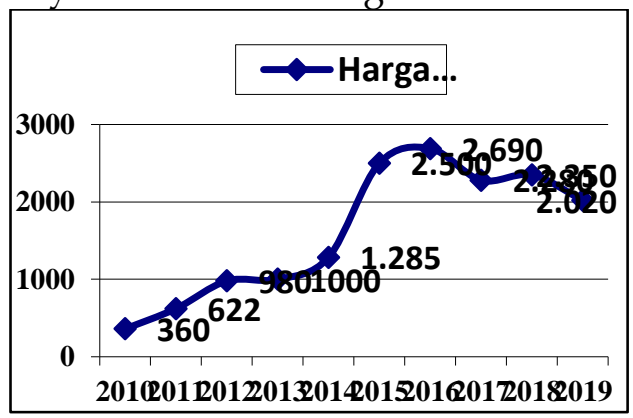

Gambar 3. Hasil Data Harga Saham PT.

Asuransi Ramayana Tbk. Tahun 2010 - 2019

Berdasarkan uraian latar belakang masalah di atas maka penulis melakukan penelitian dengan judul "Pengaruh Return On Asset (ROA) dan Earning per Share (EPS) terhadap Harga Saham pada PT.Asuransi Ramayana Tbk. Periode 20102019"

\section{TINJAUAN PUSTAKA}

1. Saham

Menurut Tjiptono Darmadji dan Hendy M. Fakhruddin (2012:5) Saham dapa didefinisikan sebagai tanda penyertaan atau kepemilikan seseprangan atau badan dalam suatu perusahaan atau perseroan terbatas. Wujud saham adalah selembar kertas yang merangkan bahwa pemilik kertas tersebut adalah pemilik perusahaan yang menerbitkan surat berharga tersebut. Porsi kepemilikan ditentukan oleh seberapa besar pernyataan yang ditanamkan perusahaan tersebut.

Menurut Irham Fahmi (2015:81) "saham merupakan salah satu instrument pasar modal yang paling banyak diminati oleh investor, karena mampu memberikan tingkat pengembalian yang menarik. Saham adalah kertas yang tercantum dengan 
jelas nilai nominal, nama perusahaan, dan diikuti dengan hak dan kewajiban yang telah dijelaskan kepada setiap pemegangnya".

Menurut Eduardus Tandelilin (2010:81) mendefinisikan bahwa saham sebagai berikut : "Saham merupakan surat bukti kepemilikan atas aset-aset perusahaan yang menerbitkan saham. Dengan memiliki saham suatu perusahaan, maka investor akan mempunyai hak terhadap pendapatan dan kekayaan perusahaan, setelah dikurangi dengan pembayaran semua kewajiban perusahaan."

Menurut Kasmir (2016:185) saham merupakan surat berharga yang bersifat kepemilikan. Artinya pemilik saham merupakan pemilik perusahaan, semakin besar saham yang dimilikinya maka semakin besar pula kekuasaannya di perusahaan tersebut. Keuntungan yang diperoleh dari saham dikenal dengan nama dividen dan pembagiannya ditentukan dalam Rapat Umum Pemegang Saham atau RUPS.

2. Return On Assets (ROA)

$\begin{array}{rrrr}\text { Return } & \text { On } & \text { Assets } & \text { (ROA) } \\ \text { merupakan } & \text { salah } & \text { satu } & \text { rasio }\end{array}$
profitabilitas. Dalam analisis laporan keuangan, rasio ini paling sering disoroti, karena mampu menunjukkan keberhasilan perusahaan menghasilkan keuntungan. Return On Assets (ROA) mampu mengukur kemampuan perusahaan menghasilkan keuntungan pada masa lampau untuk kemudian diproyeksikan di masa yang akan datang. Assets atau aktiva yang dimaksud adalah keseluruhan harta perusahaan, yang diperoleh dari modal sendiri maupun dari modal asing yang telah diubah perusahaan menjadi aktivaaktiva perusahaan yang digunakan untuk kelangsungan hidup perusahaan.

Pengertian Return On Asset menurut para ahli sebagai berikut:

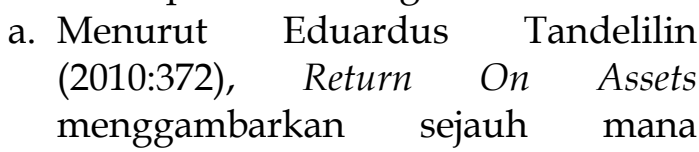
perusahaan bisa menghasilkan laba.

b. Menurut Kasmir (2016:201), Return On Assets merupakan rasio yang menunjukkan hasil atas jumlah aktiva yang digunakan dalam perusahaan.

c. Menurut Fahmi (2012:98), Return On Assets melihat sejauh mana investasi yang telah ditanamkan mampu memberikan pengembalian keuntungan sesuai dengan yang diharapkan dan investasi tersebut sebenarnya sama dengan aset perusahaan yang ditanamkan atau ditempatkan.

3. Earning Per Share (EPS)

Menurut Kasmir (2016:207), mendefinisikan Earning Per Share (EPS) sebagai berikut: "Rasio laba per lembar saham atau disebut juga rasio nilai buku, merupakan rasio untuk mengukur keberhasilan manajemen dalam mencapai keuntungan bagi pemegang saham."

Menurut Darmadji \& Fakhrudin (2012:154), mendefinisikan Earning Per Share (EPS) sebagai berikut: "Earning Per Share (EPS) adalah rasio yang mencerminkan kemampuan perusahaan dalam menghasilkan laba untuk setiap lembar saham yang beredar".

Menurut Irham Fahmi (2012:96), mendefinisikan earning per share sebagai berikut: "Earning Per Share (EPS) adalah bentuk pemberian keuntungan yang diberikan kepada para pemegang saham dari setiap lembar saham yang dimiliki."

Menurut Abdul Halim (2005:16), mendefinisikan earning per share sebagai berikut: "Laba per saham adalah keuntungan bersih setelah pajak yang diperoleh emiten dengan jumlah saham yang beredar".

\section{METODE}

Dalam penelitian menganalisis bagaimana Pengaruh variable Earning Per Share (EPS) dan Return On Asset (ROA) terhadap Harga Saham Jenis penelitian ini adalah dengan melakukan penelitian 
deskriptif kuantitatif. Penelitian deskriptif kuantitatif bertujuan untuk menjelaskan tentang fenomena yang ada menggunakan perhitungan angka-angka dari sampel data yang telah dipilih dalam penyusunan skripsi ini

Menurut Wiratna Sujarweni (2014 : 65) populasi adalah keseluruhan jumlah yang terdiri atas obyek atau subyek yang mempunyai karakteristik dan kualitas tertentu yang diterapkan oleh penelitian atau di teliti dan kemudian ditarik kesimpulannya.

Populasi adalah jumlah keseluruhan dari subyek penelitian makan populasi bukan hanya orang,tetapi obyek dan bendabenda alam yang lain. Menurut wiratana Sujarweni ( 2014 : 65 ) sample adalah bagian dari sejumlah karakteristik yang dimiliki oleh populasi yang digunakan untuk penelitan. Sample dalam penelitian ini adalah laporan keuangan PT. Asuransi Ramayana Tbk.

\section{HASIL DAN PEMBAHASAN}

Berdasarkan hasil pengolahan data dan penelitian mengenai Pengaruh Return On Asset (ROA) dan Earning Per Share (EPS) terhadap Harga Saham PT.Asuransi Ramayana Tbk. Didapat hasil sebagai berikut:

1. Pengaruh Return On Asset (ROA)

Terhadap Harga Saham

Berdasarkan hasil uji hipotesis diperoleh hasil Nilai thitung dari Return On Asset (ROA) lebih tinggi dari nilai ttabel atau (-2.893 > ttabel 2,3645) dengan nilai signifikansi 0,023 yang artinya bahwa nilai ini kurang dari tingkat signifikansi $(0,023<0,05)$. Nilai t negatif menunjukkan bahwa Return On Asset (ROA) mempunyai hubungan yang berlawanan arah dengan Harga Saham. Maka dapat disimpulkan bahwa secara parsial Return On Asset (ROA) berpengaruh signifikan terhadap perubahan Harga Saham. Hal ini berarti bahwa Ha1 diterima dan Ho1 ditolak.

2. Pengaruh Earning Per Share (EPS) terhadap Harga Saham
Berdasarkan hasil uji hipotesis diperoleh hasil Nilai Nilai thitung dari Earning Per Share (EPS) lebih besar dari nilai ttabel atau (5.234> ttabel 2,3645) dengan nilai signifikansi 0,001 yang artinya bahwa nilai ini kurang dari tingkat signifikansi $(0,001<0,05)$. Maka dapat disimpulkan bahwa secara parisal Earning Per Share (EPS) berpengaruh signifikan terhadap perubahan Harga Saham. Hal ini berarti bahwa $\mathrm{Ha} 2$ diterima dan $\mathrm{Ho} 2$ ditolak.

3. Pengaruh Return On Asset (ROA) dan Earning Per Share (EPS) terhadap Harga Saham.

Berdasarkan hasil uji hipotesis yang telah dilakukan pada hipotesis dengan menggunakan Software Statistic Product and Service Solution (SPSS) Versi 26, diperoleh hasil : Berdasarkan Output tabel 4.12, hasil uji Anova diatas diperoleh nilai Fhitung 14.073 lebih besar dari Ftabel 4,74 dengan signifikan 0,004 lebih kecil dari 0,05 atau (Fhitung $>$ FTabel) dan Fsignifikan < 0,05). Sehingga dapat disimpulkan bahwa secara simultan Return On Asset (ROA) dan Earning Per Share (EPS) secara bersamasama berpengaruh signifikan terhadap harga saham.

\section{PENUTUP}

\section{Kesimpulan}

1. Secara parsial variabel Return On Asset (ROA) berpengaruh negatif terhadap harga saham PT.Asuransi Ramayana Tbk. Dengan hasil hitung Nilai thitung dari Return On Asset (ROA) lebih tinggi dari nilai ttabel atau $(-2.893>$ ttabel 2,3645) dengan nilai signifikansi 0,023 yang artinya bahwa nilai ini kurang dari tingkat signifikansi $(0,023<0,05)$. Nilai ttabel negatif menunjukkan bahwa Return On Asset (ROA) mempunyai hubungan yang berlawanan arah dengan Harga Saham. Hal ini berarti bahwa Ha1 diterima dan Ho1 ditolak.

2. Secara parisal variable Earning Per Share (EPS) berpengaruh positif dan signifikan terhadap harga saham PT.Asuransi Ramayana Tbk. Dengan hasil hitung 
ttabel atau (5.234> ttabel 2,3645) dengan nilai signifikansi 0,001 yang artinya bahwa nilai ini kurang dari tingkat signifikansi $(0,001<0,05)$. Hal ini berarti bahwa Ha2 diterima dan $\mathrm{Ho} 2$ ditolak.

3. Secara simultan variable Return On Asset (ROA) dan Earning Per Share (EPS) berpengaruh signifikan terhadap Harga Saham PT.Asuransi Ramayana Tbk. Hal ini dibuktikan dengan nilai Fhitung 14.073 lebih besar dari Ftabel 4,74 dengan signifikan 0,004 lebih kecil dari 0,05 atau (Fhitung > FTabel) dan Fsignifikan < $0,05)$.

\section{Saran}

Berdasarkan hasil penelitian, pembahasan dan kesimpulan mengenai Return On Asset (ROA) dan Earning Per Share (EPS) terhadap Harga Saham PT.Asuransi Ramayana Tbk. penulis akan menyampaikan saran dan masukan dengan harapan dapat bermanfaat bagi perusahaan. Adapun saran-saran yang dapat diberikan dari hasil penelitian ini dapat diuraikan sebagai berikut:

1. Bagi Perusahaan

Bagi Perusahaan PT.Asuransi Ramayana Tbk. Untuk terus memperbaiki dan menunjukan kinerja yang lebih baik lagi sehingga dapat membuat investor tertarik untuk menanamkan modalnya diperusahaan. Selain itu perusahaan juga harus dapat meningkatkan kepercayaan terhadap pemegang saham dengan menunjukan kinerja perusahaan yang lebih baik dalam menyampaikan informasi mengenai perkembangan perusahaan dan laporan keuangan.

2. Bagi Investor

Bagi para investor atau calon investor disarankan agar benar-benar memperhatikan faktor-faktor fundamental atau rasio keuangan perusahaan sebelum memutuskan untuk berinvestasi diperusahaan tersebut. Khususnya investasi dalam bentuk saham hendaknya para investor melakukan pengamatan mengenai kinerja keuangan perusahaan.
3. Bagi Penelitian Selanjutnya

Diharapkan penelitian selanjutnya dapat memperpanjang periode tahun penelitian agar dapat memperoleh hasil penelitian yang lebih mencerminkan kondisi yang sesungguhnya dan menambahkan variabel lain yang dapat mempengaruhi harga saham baik faktor fundamental maupun faktor ekonomi lainnya untuk mengukur seberapa besar pengaruh terhadap Harga Saham.

\section{DAFTAR PUSTAKA}

Afandi, P., 2018. Manajemen Sumber Daya Manusia; Teori, Konsep dan Indikator, edisi 1. ed. Zanafa, Pekanbaru.

Agus, Sartono. 2011. Manajemen Keuangan Teori dan Aplikasi. Yogyakarta: BPFE.

Anwar, Z., Kahar, M. S., Rawi, R. D. P., Nurjannah, N., Suaib, H., \& Rosalina, F. (2020). Development of Interactive Video Based Powerpoint Media In Mathematics Learning. Journal of Educational Science and Technology (EST), 6(2), 167-177.

Arikunto, S, Suhardjono \& Supardi. (2013). Penelitian Tindakan Kelas. Jakarta : Bumi Aksara

Arikunto, S. 2010. Prosedur Penelitian Suatu Pendekatan Praktik. Jakarta: Rineka Cipta.

Azis,Musdalifah (2015:80),Manajemen Investasi, fundamental, teknikal, perilaku investor dan return saham. Yogyakarta:Deeppublish.

Brigham, Eugene F. Dan Houston F.Joel. 2010. Manajemen Keuangan. Buku satu. Edisi Kesebelas. Jakarta : Salemba Empat.

Darmadji, Tjiptono dan Hendy M. Fakhruddin. 2012, Pasar Modal Di Indonesia. Edisi 3. Jakarta: Salemba Empat

Eduardus Tendelilin. 2010. Portofolio dan Investasi : Teori \& Aplikasi, BPFE UGM, Yogyakarta.

Ekananda, Mahyus. 2015. Ekonometrika Dasar Untuk Penelitian Ekonomi, Sosial dan Bisnis. Jakarta: Mitra Wacana Media 
Fahmi, Irham. 2015. Pengantar Manajemen Keuangan Teori dan Soal Jawab. Bandung: Alfabeta.

Ghozali, Imam. 2011. "Aplikasi Analisis Multivariate Dengan Program SPSS". Semarang: Badan Penerbit Universitas Diponegoro.

Halim Abdul. 2005. Analisis Investasi, Edisi 2. PT Salemba Emban Patria. Jakarta.

Hanadelansa, H., \& Rawi, R. D. P. (2019). Analisis Audit Operasional Atas Pemberian Kredit Pemilikan Rumah Pada Pt Bank Rakyat Indonesia (Persero) Tbk Kantor Cabang Panakukkang Di Kota Makassar. SENTRALISASI, 8(1), 3342.

Haque, M. G., Nurjaya, N., Affandi, A., Erlangga, H., \& Sunarsi, D. (2021). Micro Financial Sharia Non-bank Strategic Analysis: a Study at BMT Beringharjo, Yogyakarta. Budapest International Research and Critics Institute (BIRCI-Journal): Humanities and Social Sciences, 4(2), 1677-1686.

Harahap, Sofyan Syafri. 2015. Analisis Kritis atas Laporan Keuangan. Edisi 1-10. Jakarta: Rajawali Pers.

Hartono, Jogiyanto.2016. Teori Portofolio dan Analisis Investasi. Edisi Kesepuluh.Yogyakarta.

Hidayat, A., \& Sunarsi, D. (2020). FaktorFaktor Yang Mempengaruhi Dana Pihak Ketiga Dan Dampaknya Terhadap Profitabilitas (Survey Pada Bpr Syariah Di Jawa Barat Tahun 2014-2017). Jurnal Proaksi, 7(1), 54-65.

Jogiyanto, H.M. (2010). Teori Portofolio dan Analisis Investasi. Edisi Ketujuh. BPFE. $\quad$ Yogyakarta.Kasmir. 2010. Pengantar Manajemen Keuangan Edisi Pertama Cetakan Kedua, Kencana Jakarta.

Kasmir. 2016. Analisis Laporan Keuangan. Jakarta: Raja Grafindo Persada.

Meilia Nur Indah Susanti, Statistik Deskriptif dan Induktif, Yogyakarta, Graha Ilmu, 2010.
Muhardi Werner R. 2013 . Analisis Laporan Keuangan Proyeksi dan Valuasi Saham.Jakarta : Salemba empat.

Musthafa. 2017. Manajemen Keuangan. Yogyakarta: CV. Andi Offset.

Nofiana, L., \& Sunarsi, D. (2020). The Influence of Inventory Round Ratio and Activities Round Ratio of Profitability (ROI). JASa (Jurnal Akuntansi, Audit dan Sistem Informasi Akuntansi), 4(1), 95-103.

Noryani, Y. B. G., Sari, W. I., Rosini, I., Munadjat, B., Sunarsi, D., \& Mahnun Mas' adi, G. (2020). Did ISO 45001, ISO 22000, ISO 14001 and ISO 9001 Influence Financial Performance? Evidence from Indonesian Industries. PalArch's Journal of Archaeology of Egypt/Egyptology, 17(7), 6930-6950.

Nuryani, Y., \& Sunarsi, D. (2020). The Effect of Current Ratio and Debt to Equity Ratio on Deviding Growth. JASa (Jurnal Akuntansi, Audit dan Sistem Informasi Akuntansi), 4(2), 304-312.

Pujiati, H., Sunarsi, D., Affandi, A., \& Anggraeni, N. (2021). Effect of ISO 9001: 2015 Quality Management Implementation in Education on School Performance. Journal of Contemporary Issues in Business and Government, 27(1), 1848-1855.

Sugiyono. (2016). Metode Penelitian Kuantitatif, Kualitatif dan R\&D. Bandung: PT Alfabet.

Suhartono, A., Jati, W., \& Sunarsi, D. (2019). Pengaruh Earning Per Share Dan Return On Asset Terhadap Harga Saham Pada PT. Bank Negara Indonesia Tbk Periode 2009-2018. Jurnal Manajemen, Bisnis dan Organisasi (JUMBO), 3(3), 182-194.

Sujarweni, V. Wiratna. 2014. Metode Penelitian: Lengkap, Praktis, dan Mudah Dipahami. Yogyakarta: Pustaka Baru Press. 